\title{
THE IMPACT OF ENTREPRENEURS CHARACTERISTICS ON THE PERFORMANCE OF SMALL MEDIUM ENTERPRISES: THE CASE OF THE KINGDOM OF SAUDI ARABIA (KSA)
}

\author{
Yasir Alfarsi
}

Western Sydney University, Sydney

This study seeks to examine the effect of entrepreneurial competencies (innovation, leadership, networking and risk-taking) on the survival of SMEs in KSA. The literature review evaluates the relationship between each of the entrepreneurial competencies and their effect on survival of SMEs worldwide. We have opted to adopt a descriptive research design. The findings reveal that entrepreneurial competencies (innovation competency, leadership competency, networking competency and risk-taking competency) of the SME owners/managers (entrepreneurs) have a positive and significant effect on the survival of SMEs in KSA. The study recommends SMEs should embrace innovation competency as a means of enhancing survival and leadership competency which is the key aspect for both survival and performance. SMEs should also embrace networking competency as a way of gaining competitive advantage and widening customer base, adopting the calculated risk-taking strategies in their operations.

Keywords: innovation competency; risk-taking; SME success; leadership; entrepreneurship; KSA

\section{Introduction and theoretical background}

In almost all economies across the globe, small and medium-sized enterprises (SMEs) are playing a significant role, being the primary engine of economic development. Since the early works of Schumpeter (Christensen, 2013), there has been a common belief that SMEs and economic development are strongly and positively correlated.

During their first three years of business operation, SMEs are usually projected to have a high failure rate. Thus, researchers, politicians and governments are concerned with improving SMEs' sustainability and gradual development. Most SMEs struggle with
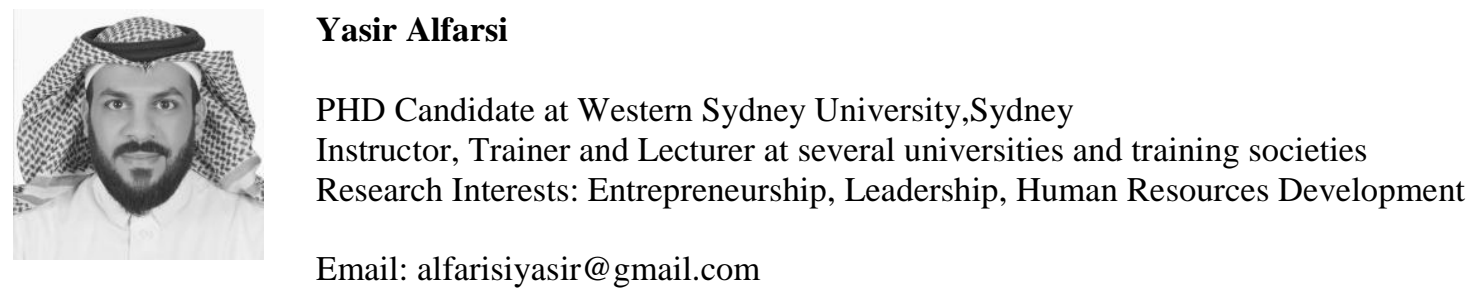


\section{THE IMPACT OF ENTREPRENEURS CHARACTERISTICS}

sustainability issues. Abdul \& Ngugi (2015) concluded that SMEs will continually learn and develop their entrepreneurial skills to thrive and grow in today's challenging and rapidly changing business environments. They agreed that business skills play a crucial role in maintaining business longevity and growth.

SMEs cover a variety of business areas as they are offering goods and services that require joint control or undertakings, family enterprises and associations. SMEs come in different shapes and sizes, and can have close relations with other enterprises within today's complex business environment. Often, these relations cause difficulties while drawing a line between a small company and a more substantial company. Adjectives of scale are often used to refer to SMEs. Economists usually prefer to group them into different classes, according to specific observable quantitative indices. For example, the number of employees is one of the most common criteria to differentiate between large and small companies (Tavakol \& Dennick, 2011)

\section{Problem Statement}

In KSA, the failure rate among SMEs is extremely high, with $2.2 \mathrm{mln}$ enterprises being closed between 2011 and 2016, according to the Micro, Small and Medium Establishments Survey (Aghion \& Jaravel, 2015). Thus, KSA has only a 10 to $20 \%$ success rate for all SMEs.

Several researchers have sought to single out the main determinants of new vendor success and failure and to come up with a comprehensive catalogue of factors which are leading to such business success or business failure (Grant,2011). The high "mortality rate" raises questions regarding these vital success factors. Although many small companies are struggling, many others actually thrive past their infancy stage and "teen" years, thus becoming true local success stories and generating prosperity for founding entrepreneurs and also supporting local communities (Al-Tabbaa \& Ankrah, 2019).

\section{Theoretical Review}

Any theory is usually designed to describe and interpret anomalies and, at times, test and broaden current understanding within the already defined limits. A theoretical review is thus a mechanism that may help or perpetuate a theory. A theoretical framework introduces and outlines the theories that illustrate why the research question has been risen (Kehinde et al, 2014). A theoretical framework includes current theories that are used in particular research, including their terms, meanings and references to applicable scholarly literature. The theoretical context demonstrates an interpretation of the theories that are applicable and linked to previous research.

Colombelli et al (2016) emphasized the need to define the theoretical context and argued that the choice of a research structure is not subjective, but represents essential personal values and awareness about the importance of the research, what actions to perform and how to apply it.

The meaning and the perception of research is vague without a theoretical context. This establishes the driving theory for constructing and promoting research and offers the basis for determining how the research as a whole should be viewed theoretically, methodologically and analytically. The theoretical structure consists of the theory selected by a researcher to 
explore a subject, as well as principles, interpretations and assumptions of the theory applicable to the subject addressed.

\section{Schumpeter's Theory of Innovation}

Truly creative solutions are never easy to discover (Barbosa, 2016). Attempting to find a different approach is essential to enable any detailed study. Various ideas will be incorporated, of course, so this is certainly not a simple job. Yet as a challenging task this can be compared to constructing the entire building on a low base (Edoka, 2015). The consistency of the company concept is crucial in this case (Bezzina, 2019). Flexibility of a product that is developed and improved depends on whether a company can effectively dominate in competition or will it struggle for survival and sustainability.

Ebbers (2014) claimed that Schumpeter's 1934 theory is the most commonly recognized innovation theory. This theory of innovation stresses entrepreneurship benefits and the incentives from the creation of new value-generating development that will extend (and change) a revolving flow of revenues. Profits resulting from consumer dominance structures with income will be forced to zero under strictly unfair circumstances. An increase in income over "natural" prices may be due to an improvement in consumer influence on the"typical" price and quantity setting in the domain of distribution or markets.

This theory is important for this analysis because sustainabilityis always related to profitability. Schumpeter's invention benefit theory reflects the monopoly status of the firms that have first-hand advantages at the markets. When leading innovators create a temporary "lock" on a product manufacturing process, this produces huge invention income, usually related to higher export values and lower supply costs at the same time.

\section{Theory of Leadership: Path-Goal Theory}

In relation to institutions, Bressler (2012) described leadership as the capacity and the willingness of an individual to control certain participants within the same organization; to consider, determine and comply with what must be achieved and how it can be accomplished; and to promote individual and collective attempts in order to attain mutual goals.

Cameron (2015) described management as a mechanism through which a specific individual influences the achievement of a collective objective by a number of people.

These definitions suggest some elements that are fundamental to the leadership phenomena, including the following: (i) leadership is a method, (ii) leadership involves manipulating others, (iii) leadership occur within a group, (iv) leadership implies reaching a certain target and (v) members and followers discuss these aims.

Leadership is not a characteristic held by only a few individuals at birth. Leadership can be characterized as a mechanism and a transactional interaction between leaders and members. Leadership as a process means that leaders are positively or negatively influenced by their followers. Cao (2012) stressed that leadership is not a sequential one-way process, but rather a two-way, collaborative experience between leaders and followers, where the leader influences her/his followers, and also vice versa. Finally, leadership is not restricted to only those members of a community who have formal powers.

According to Kochadai (2012), the path-goal paradigm is a theory based on a leadership style of behavior and management. According to it, workers should better imitate their working environment in order to reach the goals of business improvement. The leader 


\section{THE IMPACT OF ENTREPRENEURS CHARACTERISTICS}

clearly defines the aim; determines the route to the target; avoids challenges if possible; and offers the political, moral or other types of support if when required. Their goal is to inspire, encourage and serve workers who, in their turn, would become productive members of the group. The path-goal paradigm is a philosophy that can be viewed as a mechanism for leaders to recognize and select particular activities in full accordance with the desires of their staff and the work environment.

The idea of a path-goal was initially developed back in 1970 by Evans and then updated in 1971 by House. The path-goal philosophy assumes that an incentive plays a significant role in the relationship between the boss, the subordinate and the ultimate performance of the subordinate dependent on that connection.

Ali \& Bhaskar (2016) defined the path-goal principle with the help of two basic propositions. First, "One of the leader's strategic roles is to improve subordinates' psychological conditions, contributing to opportunities to succeed or job fulfilment"(Bernadette, 2019). In other words, leaders must be conscious of the measures to be taken to articulate goals and strategies and improve happiness by means of external resources which can enhance the morale of their subordinates. This author also stated that the motivating goal should be accomplished through clear actions of thechief. The principle of path-goals identifies four types of behaviour that can improve the engagement of individuals. The four types of management are then built on three attitudes displayed by subordinates: (i) happiness of subordinates, (ii) anticipation of subordinates in relation to their leaders and (iii) expectation of good output from the subordinates.

These ideas above are important for our further analysis because growing a small business is always focused on sustaining and progressing through the growth process. The behavior of the staff members should be compatible with the incentive used in relation to the employee to increase their efficiency. Actions and behaviors of the leader have the potential to influence followers, become a paradigm for role models, and provide clear directions and guidelines aimed at achieving the survival goal (Adeoye, 2015).

Management's path-goal philosophy includes considering the direction that the subordinates will follow to accomplish the predetermined by management goals. Subordinates are inspired by management to accomplish certain targets while the latter is expected to explicitly identify priorities, explain the path to be accomplished, eliminate barriers faced while reaching the priorities and enable staff members to achieve the preset objectives.

\section{Empirical Literature}

Dola (2015) conducted a cross-sectional study in Australia and Malaysia on entrepreneurial competence and SME performance. He considered entrepreneurial competency as a factor that increases the probability of achieving business success. His analysis was reliable and two experiments were significant. A qualitative methodology was used to conduct interviews with 30 entrepreneurs 20 from Australia and 10 from Malaysia who worked in the production and service sectors of SMEs. The goal was to create actions intended to assess capabilities and thus define market competencies that are specific and important in today's business settings.

The study by Børing (2015) suggested that entrepreneurial skills are directly linked with SME performance by identifying different roles performed by SMEs in management. The research claimed that businesspeople hold critical roles in their SMEs. By making 
decisions and taking action, businesspeople follow a company's strategy to ensuresustainability and growth. Entrepreneurs require market knowledge to help them recognize and identify high-quality opportunities best suited to their SMEs.

Entrepreneurs are required to carefully manage their internal and external resources to translate opportunities into positive results. For this reason, entrepreneurs are engaged in dynamic roles within their productive projects. Moreover, the very nature of SMEs' activities ensures they must train to have the necessary expertise to build a productive company. In other words, it is necessary for entrepreneurs to learn appropriate skills to guarantee their company's survival and success (Duran et al, 2016).

Another research has examined entrepreneurial skills of SMEs' owners in India. This study came to the conclusion that SMEs are struggling to manage within the currently difficult economic environment, particularly within emerging economies (Bernadette, 2019).

These findings thus demonstrate the need to find a model which would enable SMEs to navigate obstacles more easily. The study, inter alia, mentions that skills are essential for improving the chances of survival and success, especially in developing countries. The author of this study established a theoretical basis for connecting entrepreneurship skills and SMEs, taking note of the diverse roles performed by entrepreneurs within their own sector, yet focusing on the assumption that scholars concentrate on the involvement of business owners and their potential to build productive enterprises. This report also suggested that SMEs require a corporate strategy to ensure sustainability and success because of the variety of activities they are performing on a daily basis.

Griffin (2012) assumed that some sort of a corporate dream and personal ambitions influence the way SME are working. Entrepreneurship skills include experience within the corporate sector and being trained with specific expertise that can be applied in the course of making an enterprise profitable. It is necessary to equip entrepreneurs with appropriate skills that will ultimately increase their company sustainability and efficiency.

\section{Innovation Competency and SME Success}

Previous research also investigated whether there is a relationship between $R \& D$ innovation and innovative production (the share of innovative sales), as well as company age, using a broad dataset of over 100,000 Chinese companies that were founded between 2000 and 2006 (Akindele et al, 2012). The data were collected by the Chinese National Statistics Bureau and were quite suitable for evaluating new SME success, as the census covered both state and non-state firms with revenues of over RMB 5 mln annually, each company having an identification code (ID) assigned to specific companies. When a new ID was available, a client was known as a new entity (Ejermo \& Xiao,2014).

Similarly, when the ID expired, a corporation was identified as closed. The authors calculated a complementary log model with time-varying variables to regulate individual heterogeneity and found that creative companies seemed to survive longer because of R\&D rather than because of the introduction of new goods. This study was focused on emerging firms with a heterogeneous pre-sample background in particular, on assessing the probability of their survival. The authors defined the survival distinction from invention by focusing on the basic characteristics of business scale, ownership and industry. The study noted a link between R\&D or creativity and long-term business sustainability (Creswell, 2019). 


\section{THE IMPACT OF ENTREPRENEURS CHARACTERISTICS}

\section{Leadership Competency and SME Success}

Kalm et al. (2012) analyzed the effect of leadership competency on SMEs' success. A small business survey was implemented with the selected enterprises in the Lagos State Growth Region, Ikosi-Ketu, Nigeria. The research was undertaken on the basis of a sample framework and the interpretation was focused on the key results provided by a formal questionnaire (Barberis, 2013). The analysis showed that specific features of each business owner had a favorable yet negligible effect on the followers, thus resulting in personal awareness of the transformational leadership style. The study concluded that the model of transactional leadership is more suitable to encourage accomplishments in small businesses rather than to facilitate change. Thus, the study suggested that SMEs should embrace transactional leadership and strategies for the development of their industries as they expand and evolve (David, 2012).

The study by Silva (2012) considered the leadership style within Turkish industry. The surveys were undertaken between 2008 and 2010, with 343 mid-level and senior management staff of 125 high-performing manufacturing companies based in Turkey. The relationship between leadership style, learning attitude and strong performance was illustrated in a sequence of crises.

Using the SPSS statistical tool, the data collected from these questionnaires were analyzed. Factor, precision, correlation and regression analyses were used for assessment purposes. The analyses demonstrated that the effect of relationship-oriented and job-oriented leadership on the companies' performance was influenced by both aspects of learning attitude, such as engagement in learning and shared vision and experience (Taneja \& Toombs, 2014). The most important finding was that commitment to learning and also common vision and transparency mediated the effect of task-oriented leadership and relationship-oriented leadership behavior on SME success.

Another study, conducted by Adeoye, (2015) in Nigeria, examined the effect of leadership competency on the success of SMEs. The purpose of this research was to identify, over time, the factors behind the performance and the loss of companies' executives, and more specifically, to ascertain their effect on the sustainability and/or progress of SMEs. The research stems from the sampleconsisting of personnel from four major companies in the country (Cadbury Nigerian PLC, Doyin Company, Zenith Bank PLC and Access Bank PLC) and also five top university managers and academicians from Nigeria (Tehseen \& Ramayah, 2015).

The most and the least capitalized firms were selected to complete the survey. The analysis used primary data provided by this questionnaire survey. The research was centered on why business executives struggle and why they excel. The study foundthat top management leadership types, skills and techniques contribute to SMEs' success or failure. Effective leadership in an organization is not a function of the leader's strength, courage or capacity to analyze activities (David, 2012).

\section{Data Collection Procedure}

The data collection method generally indicates how respondents should be contacted to gather the needed data. This is important because data collection ensures that the results gathered are reliable and specific, and that subsequent judgements are correct. The method of data collection offers a framework for all further evaluation. In this analysis, stratified 
random sampling identified the respondents from the SMEs trading in KSA. All the respondents were first clustered by their sector (production, wholesale or retail). Then, the respondents were randomly selected, with the appropriate amount from each of these three sectors. The questionnaires were then distributed to the respondents; however, if the respondents were hesitant or distracted, the questionnaires were left with them to fill out their answers, and were then retrieved at a later date.

\section{Data Analysis and Presentation}

To test for completeness and accuracy, this study analyzed the completed questionnaires and then labelled the data to categorize the answers correctly and allocate numerical statistics to variables. To quantify the results, concise statistics were used, including percentages and frequencies. All quantitative data were measured by means of normalization in real values.

The quantitative data analyzed were then evaluated using Version 24 of SPSS (the most recent version now available), using both linear and multiple regression tests. For easier interpretation and review, the data were presented in tables and other visually convenient formats. Quantitative reports were produced through tabulation, percentages and the central trend calculation.

\section{Descriptive Statistics}

This section of the research presents the analysis of the data collected using Qualtrics, based on the questionnaires. The data were analyzed using SPSS, and will be displayed in the form of descriptive statistics and inferential statistics (including Pearson correlations), along with the results of validity and regression analyses.

\section{Regression Analysis}

The regression analysis presented here aims to test the relationship between the dependent and the independent variables, with the significance level of 5\%. If the results show a significance level below 5\%, $\mathrm{H} 0$ would be rejected and $\mathrm{H} 1$ accepted, and vice versa. All independent variables showed a significant relationship, with the significance levels below 5\%. For example, innovations (0.039), risk (0.041), leadership (0.030) and networking (0.031) all have a direct relationship with financial performance. Therefore, the following equation could be presented:

Financial performance $=0.025+0.039($ innovations $)+0.041($ risk $)+0.030($ leadership $)+$ 0.031 (networking).

This indicated that:

- for every one unit increase in innovations, the financial performance of SMEs is affected by $3.9 \%$;

- for every one unit increase in risk, the financial performance of SMEs is affected by $4.1 \%$

- for every one unit increase in leadership, the financial performance of SMEs is affected by $3 \%$;

- for every one unit increase in networking, the financial performance of SMEs is affected by $3.1 \%$. 
THE IMPACT OF ENTREPRENEURS CHARACTERISTICS

Table1 - Regression Analysis results

(Source: calculated by the author)

\begin{tabular}{|c|c|c|c|c|}
\hline \multicolumn{4}{|l|}{ Model Summary } \\
\hline Model & $\mathrm{R}$ & $\mathrm{R}^{2}$ & Adjusted $\mathrm{R}^{2}$ & $\begin{array}{c}\text { Std Error of the } \\
\text { Estimate }\end{array}$ \\
\hline 1 & $.488^{\mathrm{a}}$ & .446 & .417 & .02414 \\
\hline \multicolumn{4}{|l}{ a. Predictors: (constant), networking, risk, innovations, leadership } \\
\hline
\end{tabular}

\begin{tabular}{|l|l|c|c|c|c|c|}
\hline \multicolumn{7}{|c|}{ ANOVA $^{\mathrm{a}}$} \\
\hline \multicolumn{2}{|c|}{ Model } & $\begin{array}{c}\text { Sum of } \\
\text { Squares }\end{array}$ & df & Mean Square & F & Sig. \\
\hline \multirow{3}{*}{1} & Regression & .022 & 4 & .007 & 12.047 & $.000 \mathrm{~b}$ \\
\cline { 2 - 7 } & Residual & .051 & 91 & .001 & & \\
\cline { 2 - 7 } & Total & .081 & 95 & & & \\
\multicolumn{2}{|l}{ a. Dependent variable: financial performance } \\
\hline \multicolumn{2}{|l}{ b. Predictors: (constant), networking, risk, innovations, leadership } \\
\hline
\end{tabular}

\begin{tabular}{|c|c|c|c|c|c|c|}
\hline & & & Coefficients & & & \\
\hline & del & & $\begin{array}{l}\text { ardised } \\
\text { ff. }\end{array}$ & $\begin{array}{l}\text { Standardised } \\
\text { Coeff. }\end{array}$ & $\mathrm{T}$ & Sig. \\
\hline & & B & Std. Error & Beta & & \\
\hline & (Constant) & .027 & .011 & & 2.429 & .025 \\
\hline & Innovations & .289 & .121 & .081 & 2.388 & .039 \\
\hline 1 & Risk & .282 & .128 & .198 & 2.031 & .041 \\
\hline & Leadership & .274 & .105 & .080 & 2.609 & .030 \\
\hline & Networking & .340 & .091 & .377 & 3.738 & .031 \\
\hline
\end{tabular}

Thus, the following hypotheses could be now validated:

H10: There is no statistical evidence of a relationship between innovation competency and SMEs' success in KSA (rejected).

H11: There is statistical evidence of a relationship between innovation competency and SMEs' success in KSA (accepted).

H20: There is no statistical evidence of a relationship between leadership competency and SMEs' success in KSA (rejected).

H21: There is statistical evidence of a relationship between leadership competency and SMEs' success in KSA (accepted).

H30: There is no statistical evidence of a relationship between networking competency and SMEs' success in KSA (rejected).

H31: There is statistical evidence of a relationship between networking competency and SMEs' success in KSA (accepted).

H40: There is no statistical evidence of a relationship between risk-taking competency and SMEs' success in KSA (rejected).

H41: There is statistical evidence of a relationship between risk-taking competency and SMEs' success in KSA (accepted). 


\section{Descriptive Statistics}

Tab. 2 presents the statistics related to innovation and its importance for financial performance, obtained from implementing a Likert scale ranging from 1 to 7.

The results show the mean of 2 for all questions, which meant that the participants strongly agreed and were implementing innovation practices while operating their SMEs in KSA. It was obvious that they were focusing on mobile banking, mobile payments, digitalization and e-commerce. This is considered a good indicator that demonstrates that innovation tends to have a direct effect on the performance and sustainability of SMEs in KSA.

Table2 - Descriptive Statistics

(Source: calculated by the author)

\begin{tabular}{|l|c|c|c|c|c|}
\hline & $\mathrm{N}$ & Min. & Max. & $\begin{array}{c}\text { Mea } \\
\mathrm{n}\end{array}$ & $\begin{array}{c}\text { Std } \\
\text { Dev. }\end{array}$ \\
\hline $\begin{array}{l}\text { You have a creative and innovative business } \\
\text { mindset }\end{array}$ & 123 & 1 & 7 & 2.18 & 1.124 \\
\hline $\begin{array}{l}\text { You have the basics of business management that } \\
\text { help you be an entrepreneur }\end{array}$ & 123 & 1 & 6 & 2.08 & 1.083 \\
\hline $\begin{array}{l}\text { You have sufficient knowledge of how to access } \\
\text { financing for your business }\end{array}$ & 123 & 1 & 7 & 2.77 & 1.311 \\
\hline $\begin{array}{l}\text { You have knowledge about those with experience } \\
\text { in your business and the ability to communicate } \\
\text { with them }\end{array}$ & 123 & 1 & 6 & 2.16 & 1.003 \\
\hline $\begin{array}{l}\text { You experience great pleasure when doing your } \\
\text { business }\end{array}$ & 123 & 1 & 5 & 1.52 & .853 \\
\hline $\begin{array}{l}\text { You have varied and useful ideas to make your } \\
\text { business successful }\end{array}$ & 123 & 1 & 4 & 1.83 & .732 \\
\hline $\begin{array}{l}\text { You had sufficient knowledge about the field of } \\
\text { entrepreneurship in the Kingdom before you } \\
\text { started your business }\end{array}$ & 123 & 1 & 7 & 3.10 & 1.490 \\
\hline $\begin{array}{l}\text { You have the ability to manage operations and } \\
\text { marketing in your business }\end{array}$ & 123 & 1 & 5 & 2.32 & .989 \\
\hline $\begin{array}{l}\text { You have the ability to acquire materials of } \\
\text { appropriate cost and high quality that serve your } \\
\text { business's products }\end{array}$ & 123 & 1 & 7 & 2.16 & 1.242 \\
\hline $\begin{array}{l}\text { You insist on making your business successful, } \\
\text { regardless of the suitability of the type of business } \\
\text { to your field of interest or specialisation }\end{array}$ & 123 & 1 & 7 & 2.31 & 1.173 \\
\hline Valid N & 123 & & & & \\
\hline
\end{tabular}

\section{Leadership Competency}

Tab. 3 presents the statistics related to leadership and its importance for financial performance, obtained from implementing a Likert scale ranging from 1 to 7 . The results show the mean of 2 for some questions and the mean of 1.5 for other questions. This 


\section{THE IMPACT OF ENTREPRENEURS CHARACTERISTICS}

indicates that the participants strongly agreed and were implementing risk practices while operating their SMEs in KSA. It was obvious that they focused on implementing leadership practices in the workplace and were especially focused on motivating and communicating with employees.

This can be also seen in Tab. 3, as the mean of questions was between 1 and 2, which falls between "strongly agree" and "agree" according to the research scale. This is considered a good indicator and means that leadership practices tend to have a direct effect on the performance and sustainability of SMEs in KSA.

Table 3 - Leadership Competency

(Source: calculated by the author)

\begin{tabular}{|l|c|c|c|c|c|}
\hline & $\mathrm{N}$ & Min. & $\begin{array}{c}\text { Ma } \\
\text { x. }\end{array}$ & $\begin{array}{c}\text { Mea } \\
\mathrm{n}\end{array}$ & $\begin{array}{c}\text { Std } \\
\text { Dev. }\end{array}$ \\
\hline $\begin{array}{l}\text { You have a high ability to handle and solve problems } \\
\text { in your business }\end{array}$ & 123 & 1 & 6 & 1.95 & .965 \\
\hline $\begin{array}{l}\text { You have the ability to compete against those who } \\
\text { have the same business }\end{array}$ & 123 & 1 & 7 & 2.37 & 1.162 \\
\hline You are highly accomplished and challenging & 123 & 1 & 5 & 1.71 & .885 \\
\hline $\begin{array}{l}\text { You have high confidence in your capabilities and } \\
\text { the potential to make your business successful }\end{array}$ & 123 & 1 & 4 & 1.55 & .715 \\
\hline $\begin{array}{l}\text { You constantly seek to own a business that you run } \\
\text { independently }\end{array}$ & 123 & 1 & 7 & 2.51 & 1.231 \\
\hline $\begin{array}{l}\text { You have a clear and thoughtful future vision for } \\
\text { your enterprise growth and development }\end{array}$ & 123 & 1 & 6 & 2.44 & 1.003 \\
\hline $\begin{array}{l}\text { You have the ability to efficiently manage the } \\
\text { expenses and financial resources of your business }\end{array}$ & 123 & 1 & 6 & 2.09 & 1.027 \\
\hline $\begin{array}{l}\text { You have the ability to efficiently manage the human } \\
\text { resources of your business }\end{array}$ & 123 & 1 & 7 & 2.21 & 1.329 \\
\hline $\begin{array}{l}\text { You have sufficient knowledge of the leadership } \\
\text { skills and techniques that contribute to the success of } \\
\text { your business }\end{array}$ & 123 & 1 & 7 & 2.14 & 1.393 \\
\hline $\begin{array}{l}\text { You insist on producing more new services and } \\
\text { products in your business }\end{array}$ & 123 & 1 & 7 & 2.52 & 1.244 \\
\hline Valid N & 123 & & & & \\
\hline
\end{tabular}

\section{Collinearity}

The collinearity test presented in Table 4 was carried out to test the correlations between the variables, and the following results were obtained:

- innovations and financial performance $=0.172$,

- $\quad$ leadership and financial performance $=0.153$.

Given that all the numbers were below 0.7 , this indicates there was no multicollinearity between the variables and the correlations were fine. 
Table 4 - Collinearity

(Source: calculated by the author)

\begin{tabular}{|c|c|c|c|c|c|c|}
\hline & & $\begin{array}{c}\text { Financial } \\
\text { Performance }\end{array}$ & Innovation & Risk & Leadership & Networking \\
\hline \multirow{3}{*}{$\begin{array}{l}\text { Financial } \\
\text { perfor- } \\
\text { mance }\end{array}$} & $\begin{array}{l}\text { Pearson } \\
\text { correlation }\end{array}$ & 1 & .172 & .086 & .153 & 139 \\
\hline & Sig. (2-tailed) & & .094 & .403 & .136 & .176 \\
\hline & $\mathrm{N}$ & 123 & 123 & 123 & 123 & 123 \\
\hline \multirow{3}{*}{ Innovation } & $\begin{array}{l}\text { Pearson } \\
\text { correlation }\end{array}$ & .172 & 1 & $.656 * *$ & $.699 * *$ & $.632 * *$ \\
\hline & Sig. (2-tailed) & .094 & & .000 & .000 & .000 \\
\hline & $\mathrm{N}$ & 123 & 123 & 123 & 123 & 123 \\
\hline \multirow{3}{*}{ Leadership } & $\begin{array}{l}\text { Pearson } \\
\text { correlation }\end{array}$ & .153 & $.699 * *$ & $.687 * *$ & 1 & $.736^{* * *}$ \\
\hline & Sig. (2-tailed) & .136 & .000 & .000 & & .000 \\
\hline & $\mathrm{N}$ & 123 & 123 & 123 & 123 & 123 \\
\hline
\end{tabular}

Validity and Reliability Analysis

Validity and reliability analysis was conducted to test whether the collected data were valid and reliable. The rule of thumb states that, if the Cronbach's alpha is lower than 0.5 , this means that the collected data are not reliable. If the Cronbach's alpha is between 0.5 and 0.7, the collected data are reliable. In this study, Cronbach's alpha assumes reliable data for all the variables, since all the indicators were above 0.7 (see Tab. 5). This means that the collected data were reliable and ready for statistical analysis.

Table 5 - Validity and Reliability

(Source: calculated by the author)

\begin{tabular}{|l|c|}
\hline Component Matrix $^{\mathrm{a}}$ \\
\hline & Component \\
\cline { 2 - 2 } & 1 \\
\hline Innovation & .857 \\
\hline Leadership & .900 \\
\hline Extraction method: principal component analysis \\
\hline a. One component extracted \\
\hline
\end{tabular}

\section{Conclusions and Contributions}

\section{Innovation Competency}

This study recommends SMEs to use innovation skills in order to enhance their success through management. SMEs may also increase their chances for business success through development of innovative product lines and adoption of various creative concepts. SMEs are also expected to invest in new markets and encourage their employees to be more innovative to improve their performance and survival chances. 


\section{THE IMPACT OF ENTREPRENEURS CHARACTERISTICS}

\section{Leadership Competency}

This study further advises that owners of SMEs should develop their leadership skills as a core feature of organisational success and sustainability, in accordance with the findings of our analysis. As leaders, owners should follow clear methods of communication to promote cohesion and increasingly delegate duties as a mechanism of training among employees, preferably through technological communication channels. As leaders, SME managers should ensure they motivate staff through leading by example.

Moreover, this study advises that SME managers should ensure that consistent strategies are established to improve sustainability by concentrating on a common business target. All these aspects are achievable if leaders seek to actively develop their leadership skills according to their organizational objectives.

\section{Study Limitations}

The key drawback of this study was the secrecy of some SME owners and the fact that they were not readily prepared to disclose certain information. The researchers managed to partially overcome this restriction by means of providing a letter from the university, assuring the interviewees that the information provided would be used solely for academic purposes and would be kept confidential.

The investigator has also promised to disclose the final results of the analysis to the respondents. The research was focused on questionnaires that the respondents had provided instant responses by telephone. However, several respondents did not have time to engage in the study immediately because of their business and other obligations. Thus, they were given a chance to fill out the questionnaires in the time convenient for them, at a later date.

Further, while this study addressed the defined research variables, many other variables were not addressed in this research at all, and it is recommended that these other variables should be investigated in future research. In addition, the sample number for the study is relatively low, primarily due to time constraints and the overall situation with the COVID-19 pandemic. Finally, this research was based on a quantitative methodology only, while the

qualitative methodological part was absent as such, again, due to time constraints and COVID-19.

\section{References:}

Abdul, R. O., \& Ngugi, K. (2015). Influence of entrepreneurial competencies on the growth of small and medium enterprises in Kenya: A case of Nairobi County. International Journal of Social Sciences and Entrepreneurship, 4(4), 1-22.

Adeoye, A. A. (2015). The effect of entrepreneurship on economy growth and development in Nigeria. International Journal of Development and Economic Sustainability, 3(2), 49-65.

Aghion, P., \& Jaravel, X. (2015).Knowledge spillovers, innovation and growth. The Economic Journal, 125 (583), 533-573.

Akindele, R. I., Oginni, B. O., \& Omseoyele, S. O. (2012). Survival of private universities in Nigeria: Issues, challenges and prospects. International Journal of Innovative Research in Management, 1(2), 30-43. 
Al-Tabbaa, O., \& Ankrah, S. (2019). Social capital to facilitate 'engineered' university-industry collaboration for technology transfer: A dynamic perspective. Technological Forecasting and Social Change, 104 (1), 1-15.

Ali, Z., \& Bhaskar, S. B. (2016). Basic statistical tools in research and data analysis. Indian Journal of Statistic, 60(9), 662-678.

Barberis, N. C. (2013). Thirty years of prospect theory in economics: A review and assessment. The Journal of Economic Perspectives, 27(1), 173-195.

Barbosa, E. G. (2016). Determinants of small business survival: The case of very small enterprises of the traditional manufacturing sectors in Brazil. Available at: https://mpra.ub.unimuenchen.de/73346/

Bernadette, M. (2019).The relationship between business management training and small and medium sized enterprises' growth in Kenya (Unpublished Doctoral dissertation). Kenyatta University, Nairobi.

Bezzina, F. (2019).Characteristics of the Maltese entrepreneur. International Journal of Arts and Sciences, 3(7), 292-312.

Børing, P. (2015). The effects of firms' R\&D and innovation activities on their survival: A competing risks analysis. Empirical Economics, 49(3), 1045-1069.

Bressler, M. S. (2012). How small businesses master the art of competition through superior competitive advantage. Journal of Management and Marketing Research, 11(1), 2-9.

Christensen, C. (2013). The innovator's dilemma: When new technologies cause great firms to fail. Boston, MA: Harvard Business Review Press.

Colombelli, A., Krafft, J., \& Vivarelli, M. (2016). To be born is not enough: The key role of innovative start-ups. Small Business Economics, 2, 1-15.

Creswell, J. W. (2019). Research design: Qualitative, quantitative, and mixed methods approaches. London, England: Sage Publications.

David, G. (2012). Testing statistical assumptions. Raleigh, North Carolina: Statistical Publishing Associates.

Dola, G. A. (2015). The effect of transformational leadership on the performance of employees in Kenya: The case of Kenya Wildlife Service (Unpublished Doctoral dissertation). Kenyatta University, Nairobi.

Duran, P., Kammerlander, N., Van Essen, M., \& Zellweger, T. (2016).Doing more with less: Innovation input and output in family firms. Academy of Management Journal, 59(4), 12241264.

Ebbers, J. J. (2014). Networking behavior and contracting relationships among entrepreneurs in business incubators. Entrepreneurship Theory and Practice, 38(5), 1159-1181.

Edoka, J. (2015). Effective leadership and organizational performance: A case study of National Youth Service Corps (NYSC) Kogi State (Unpublished Doctoral dissertation). University of Nigeria, Nigeria.

Ejermo, O., \& Xiao, J. (2014). Entrepreneurship and survival over the business cycle: How do new technology-based firms differ? Small Business Economics, 43(2), 411-426.

Griffin, R. W. (2012). Managing new venture formation and entrepreneurship. In: R. W. Griffin (Ed.), Management: Principles and practices. Stamford, CT: South-Western Cengage Learning. 


\section{THE IMPACT OF ENTREPRENEURS CHARACTERISTICS}

Kalm, M. (2012). The impact of networking on firm performance: Evidence from small and mediumsized firms in emerging technology areas (No. 1278). Available at: https://www.etla.fi/wpcontent/uploads/2012/09/dp1278.pdf.

Kehinde, J., Idris, A., \&Oluitan, R. (2014). Organizational survival: The effects of leadership skill and strategy. Science Journal of Business and Management, 2(2), 44-49.

Kochadai, M. (2012). Entrepreneurial competency: A study with reference to socially and economically backward communities in Chennai City (Unpublished Doctoral dissertation). Pondicherry University, Pondicherry.

Silva, T. D. S. (2012). Innovation at Polisport: Discovering the drivers and impact on performance at a Portuguese SME (Unpublished Doctoral dissertation). Nova School of Business EconomicsUNL, Nova, Portugal.

Taneja, S., \& Toombs, L. (2014).Putting a face on small businesses: Visibility, viability, and sustainability the impact of social media on small business marketing. Academy of Marketing Studies Journal, 18(1), 249-260.

Tavakol, M., \& Dennick, R. (2011). Making sense of Cronbach's alpha. International Journal of Medical Education, 2, 53-55.

Tehseen, S., \& Ramayah, T. (2015). Entrepreneurial competencies and SMEs business success: The contingent role of external integration. Mediterranean Journal of Social Sciences, 6(1), 50-61.

Paper submitted

02 March 2021

Paper accepted for publishing

10 April 2021

Paper published online

31 May2021 